\title{
PERTUMBUHAN LIRIOMYZA SATIVAE BLANCARD DAN NESIDIOCORIS TENUIS REUTER PADA BEBERAPA GALUR SERTA VARIETAS TOMAT
}

\section{POPULATION GROWTH OF LIRIOMYZA SATIVAE BLANCARD AND NESIDIOCORIS TENUIS REUTER ON SEVERAL STRAIN AND VARITIES OF TOMATOES}

\author{
D.T. Sembel", T. Manoi", M. Tulung*, J. Pongoh*, M. Meray dan M. Ratulangi* \\ * Dosen Fakultas Pertanian Unsrat Manado (email: sembeldt@yahoo.co.id; dantje.sembel@unsrat.ac.id \\ ** Staf Balai Perlindungan Tanaman Pangan dan Hortikultura Sulawesi Utara.
}

\begin{abstract}
The objectives of thiswork was to study the difference on the population growths of these two pests of tomatoon plots with and without pesticide sprayings for 5 strains of tomatoes obtained from AVRDC (G1-G6) and 4 varieties (G7-G10) available in the local market. The population of leafminer started growing a week after replanting and reached the peak 7-8 weeks then it started declining until 12 weeks after replanting.Statistical analysis showed that there was no significant difference on the population growth of L. sativae on sprayed plots for all strains from AVRDCand varieties G7-G9 but it was significant different from $\mathrm{G} 10$. There was also no significant difference on population growths of $L$. sativae for strains $\mathrm{G1}, \mathrm{G} 2$ and $\mathrm{G} 4$ to $\mathrm{G} 7$ and G8 but it was significant different with strains G5,G9 and $\mathrm{G} 10$ on sprayed plots and plots without spraying.The population of N. tenuis grew quicker and reached the peak on week 6 after replanting and starts declining until week $12^{\text {th }}$. Statistical analysis showed that there was no significant difference on the population of $N$. tenuis on all strains and varieties $G 7$ and $G 8$ on plots without spraying but there was significant difference for all strains and varieties G7-G9 with variety G10.
\end{abstract}

Kata kunci: Tomatoes, Liriomyza sativae, Nesidiocoris tenuis

\begin{abstract}
ABSTRAK
Tujuan penelitian ini untuk mengetahui perbedaan pertumbuhan populasihama penggorok daun, Liriomyza sativae dan kepik tomat mirid, Nesidiocoris tenuis pada petak tanpa penyemprotan pestisida dan dengan penyemprotan pestisida pada 5 galur tomat yang berasal dari AVRDC dan 4 varietas tomat yang tersedia di pasaran.Populasi penggorok daun, $L$. sativae mulai terlihat sejak seminggu sesudah dipindahkan dan mencapai puncak 7-8 minggu kemudian populasihama mulai menurun sampai 12 minggu sesudah tanaman dipindahkan. Hasil analisis statistika tidak terdapat perbedaan nyata terhadap populasi $L$. sativae pada petak yang disemprot pestisida untuk semua galur dari AVRDC serta varietas $\mathrm{G} 7-\mathrm{G} 9$ tapi berbeda nyata dengan varietas $\mathrm{G} 10$. Juga, tidak terdapat perbedaan yang nyata antara populasi L. sativae untuk galur G1,G2, G4,G7dan G8 tetapi berbeda nyata dengan galur G5, G9 dan G10 pada petak yang tidak disemprot pestisida. Populasi $L$. sativae terendah pada varietas G10 baik pada petak penyemprotan maupunpetak tanpa penyemprotan pestisida.Populasi $N$. tenuis berkembang lebih cepat dan mencapai puncak pada minggu ke enam dan ke tujuh serta menurun sampai minggu ke 12 sesudah tanaman tomat dipindahkan. Hasil analisis statistika menunjukkan tidak terdapat perbedaan yang nyata terhadap populasi $N$. tenuis untuk semua galur dari AVRDC serta varietas $\mathrm{G} 7$ dan $\mathrm{G} 8$ pada petak tanpa penyemprotan tetapi terdapat perbedaan yang nyata antara semua galur dan varietas $\mathrm{G} 7-\mathrm{G} 9$ dengan varietas $\mathrm{G} 10$.
\end{abstract}

Kata kunci: Tomat, Liriomyza sativae, Nesidiocoris tenuis

Eugenia Volume 17 No. 1 April 2011 


\section{PENDAHULUAN}

Tomat (Lycopersicum esculentum Mill.) adalah tanaman sayuran atau buah-buahan yang mengandung gizi yang baik untuk kesehatan manusia. Tomat adalah tanaman sayuran yang penting bagi petani karena dapat dijual dengan mudah di pasar meskipun harganya sangat berfluktuasi sesuai musim (Sembel: Komunikasi pribadi dengan petani tomat, 2010). Sejak awal tahun 2000an hampir semua petani menanam tomat varietas baru yang berukuran tinggi 1.5-2.00 meter atau lebih dan bertumbuh tegak dan menggunakan tajir bambu untuk menahan tanaman agar tetap bertumbuh tegak. Sebelumnya hampir semua petani menanam tomat lokal yang tingginya sekitar1.0 meter dan memiliki banyak cabang horizontal sehingga pada saat berbuah banyak cabang yang merayap di atas permukaan tanah dan mengakibatkan pembusukan buah tomat. Dalam sebuah tomat terdapat 30 kalori, vitamin $C$ $40 \mathrm{mg}$, vitamin A $1.500 \mathrm{~S} . \mathrm{I}$, zat besi, dan kalium (Tugiyono, 2005).

Produksi tomat Sulawesi Utara sesuai data dari Badan Pusat Statistik dan Direktorat Jenderal Bina Produksi Hortikultura tahun 20002006, menunjukkan kecenderungan berfluktuasi dari tahun ke tahun, yakni berturut-turut dari 6,511 ton, 16,520 ton, 13,78 ton, 19,911 ton, 30,312 ton, 33,476 ton, dan 22,793 ton (www.deptan. go.id/infoeksekutif/horti/EIS07/Prod.Tomat3.htm).

Fluktuasi produksi tomat tersebut dapat dipengaruhi antara lain oleh musim, luas areal pengusahaan, sistem bercocok tanam serta serangan hama dan penyakit tanaman. Luas tanaman tomat di seluruh Kabupaten Minahasa (Minahasa Raya), Sulawesi Utara sampai dengan Maret 2010 adalah 2613 ha dengan produksi antara 40-60 ton per ha (Dinas Pertanian Pangan dan Hortikultura, Sulawesi Utara, 2010).

Terdapat banyak jenis hama pada tanaman tomat diantaranya adalah Bemisia tabaci (Genadius) (Hemiptera:Aleyrodidae), Aphis sp. (Hemiptera: Aphidae), Heliothis armigera, Agrotis ipsilon, Spodoptera exigua dan S. litura ke empat spesies ini adalah dari ordo Lepidoptera, famili Noctuidae; Bactrocera papayae (Diptera;
Tephritidae), Nesidiocoris tenuis (= Cyrtopeltis tenuis) (Hemiptera: Miridae) dan Liriomyza sativae (Diptera: Agromyzidae) (Kalshoven, 1981; Sembel $d k k$, 2003a, Sembel dkk. 2008). Hama-hama serangga, $N$. tenuis dan $L$. sativae merupakan hama baru yang menjadi masalah serius pada tanaman tomat di Sulawesi Utara sejak awal tahun 2000an (Sembel $d k k$. 2008). Serangan hama penggorok daun, $L$. sativae biasanya menyerang daun tanaman tomat dengan menggorok daun dan membentuk spiral panjang dan berkelit serta merusak jaringan daun sehingga pada ahkirnya daun mengering. Bila serangan terjadi pada waktu tanaman masih berumur muda (1-2 minggu) maka tanaman tersebut akan mati. Hasil survey yang dilakukan pada tahun 2004 menunjukkan bahwa serangan penggorok daun, $L$. sativae yang hebat dapat menyebabkan tanaman tomat mati dan gagal panen (Sembel dkk., 2003b dan 2004). Hama penggorok daun ini bersifat polifagus karena menyerang banyak jenis tanaman (Sembel $d k k$. 2003a). Hasil penelitian tentang parasitoids pada berbagai jenis penggorok daun yang ditemukan di Sulawesi Utara pada periode tahun 2001 sampai 2003 dan tahun 2009 ditemukan lima jenis parasitoids yaitu, Gronotoma micromorpha, Neochrysocharis sp, Quadrastichus sp., Opius sp. Dan yang paling dominan adalah Hemiptarsenemus varicornis (Girault). Parasitasi oleh parasitoid, $H$. varicornis terhadap penggorok daun sampai $48.65 \%$ sedangkan parasitoid-parasitoid lainnya hanya di bawah 20\% (Kandowangko et al., 2003; Sembel dkk., 2009).

Kepik, $N$. tenuis adalah serangga yang berstatus ganda yaitu sebagai hama dan atau predator (Arno et el., 2010; Calvo, et al., 2009). Serangga kepik ini dilaporkan sebagai hama pada tanaman tembakau di India, daerah Mediteranian, dan Mesir dan di Perancis Selatan sebagai sebagai hama tanaman tomat (Patel, 1980; Torreno, 1994, El-Dessouki et al., 1976). Arno et al., (2006) melaporkan bahwa tingkat serangan hama kepik ini terutama pembentukan cincin coklat pada tangkai tanaman akan tergantung pada populasi hama yang juga bertindak sebagai predator. Calvo et al., (2008) dan Sanchez (2008) juga melaporkan bahwa tingkat serangan hama ini akan tergantung 
pada populasi dari serangga yang menjadi inang $N$. tenuis. Bila inang seperti kutu daun, dan serangga kecil lainnya tersedia sebagai makanan $N$. tenuis maka tingkat serangan hama ini akan berkurang. Budiman dkk. (2010) melaporkan bahwa N. tenuis mulai menyerang tanaman tomat pada bagian batang dan tangkai bunga sejak nimfa instar satu sampai imago. Gejala serangan hama ini ialah terjadinya cincin bewarna coklat pada cabang yang terserang dan tangkai bunga yang menyebabkan gugurnya bunga tomat. Shepard, dkk. (1999), melaporkan bahwa $N$. tenuis dapat menyerang bunga tomat di Pulau Jawa, Indonesia dan juga dapat bersifat sebagai predator pada kutu daun Aphis sp. Arno et al (2010), juga melaporkan bahwa $N$. tenuis dapat merupakan sebagai predator umum dan hama pada tanaman tomat di Spanyol.

Di kepulauan Kanari dan Spanyol Selatan kepik kebul, Bemessia tabaci merupakan mangsa utama dari N. tenuis (Carnero et al., 2000; Calvo et al., 2008, Sanchez, 2008 dan Albajes et al., 2006). Urbaneja dan Nannini (2003) melaporkan bahwa $N$. tenuis berpotensi sebagai musuh alami, yakni sebagai predator pada kutu putih (Bemicia tabaci).

Penelitian ini bertujuan untuk mempelajari perbedaan padat pertumbuhan populasi penggorok daun Liriomyza sativae, dan kepik tomat, Nesidiocoris tenuis pada beberapa galur dan varietas tanaman tomat untuk petak tanaman tomat yang disemprot dengan pestisida dan tanpa disemprot dengan pestisida.

Terdapat perbedaan pertumbuhan populasi hama $L$. sativae dan $N$. tenuis pada berbagai galur dan varietas tomat baik yang disemprot dengan pestisida dan tanpa penyemprotan pestisida. Galur-galur tomat yang berasal dari AVRDC lebih tahan terhadap infestasi hama dari pada varietas yang sudah ada di Sulawesi Utara.

\section{METODE PENELITIAN}

\section{Tempat dan Waktu Penelitian}

Penelitian ini dilaksanakan di lahan milik petani di Desa Toure, Kecamatan Tompaso, Kabupaten Minahasa, Provinsi Sulawesi Utara dan Laboratorium Hama dan Penyakit Fakultas
Pertanian Unsrat Manado. Penelitian ini dilaksanakan sejak Maret sampai dengan Juli 2009.

\section{Bahan dan Alat}

Bahan: lahan seluas $5 \times 2$ meter sebanyak 10 petak, benih tomat lima galur dari AVRDC Thailand yaitu G1 $=$ WVCT-6, G2 $=$ WVCT $-2, \mathrm{G} 4=$ WVCT-8, G5 = WVCT-5 dan G6=WVCT-7 serta 4 varietas yaitu: $\mathrm{G} 7=\mathrm{VAR}$. Amelia, $\mathrm{G} 8=$ varietas Anna, $\mathrm{G} 9=$ varietas Permata dan $\mathrm{G} 10=$ Varietas Chung, polibag, insektisida Agrimec 18 EC (abamectin), Buldok 25 EC (Beta cyfluthrin), fungisida antrakol 70WP (propineb 70\%) dan Amistartop 325 EC (azoxystrobin + difenoconazole), zat tumbuh (Gandasil D, Sprint dan Primatan), pupuk kandang, poska (NPK), dan kain kasa halus. Alat: ajir bambu, aspirator, alat semprot, jaring serangga, kamera, loupe, mikroskop.

\section{Metode Penelitian}

Penelitian ini dilakukan dengan percobaan faktorial (split plot design) dengan dua ulangan. Sebagai petak utama adalah penyemprotan dengan dua taraf yaitu P1= Tanpa Penyemprotan tapi dengan menggunakan zat tumbuh (sprint, primatan dan gandasil) dan P2 = Dengan penyemprotan (Agrimec, manzed, antrakol, sprint, gandasil dan primatan) sesuai praktek yang dilakukan oleh petan setempat. Anak petak adalah genotipe (galur dan varietas) yaitu G1, G2, G4, G5, G6, G7, G8, G9, dan G10. Jumlah petak keseluruhan adalah 36 petak dan setiap petak berisi 40 tanaman tomat.

\section{Prosedur Kerja}

Pesemaian, penanaman, pemasangn ajir

bambu, pemangkasan, penyiraman dan pemupukan dilakukan sesuai dengan kebiasaan petani. Pengendalian hama pada petak penyemprotan dilakukan dengan menggunakan pestisida Agrimec pada petak dengan penyemprotan pestisida. Pada petak tanpa pestisida disemprotkan bioagen Thurex dengan bahan aktif Bacillus thuringiensis manakala terlihat adanya serangan hama. Panen dilakukan pertama kali pada umur 70 hari setelah pindah tanam dan selanjutnya panen dilakukan setiap minggu. 
Perhitungan padat populasi $L$. sativae, $N$. tenuis dan B. tabaci.

Perhitungan padat populasi L. sativae dilakukan dengan menggunakan alat penghitung (counter) dengan menghitung jumlah bentuk dewasa di 32 pohon tomat per petak. Empat pohon di setiap pinggiran petak tidak masuk dalam perhitungan serangga.

Perhitungan padat populasi $N$. tenuis, $L$. sativae dan $B$. tabaci dilakukan dengan menghitung jumlah masing-masing hama pada 32 pohon dari setiap petak perlakuan. Di hitung rata-rata masingmasing penggorok daun, kepik mirid tomat dan kutu kebul per pohon. Perhitungan sampel dilakukan setiap dua minggu yang dimulai 15 hari sesudah pindah tanam (hspt) sampai dengan $90 \mathrm{hspt}$.

\section{Analisis Data}

Data pengamatan dianalis dengan analisis keragaman dan jika berbeda nyata dilanjutkan dengan uji beda nyata terkecil (BNT)

\section{HASIL DAN PEMBAHASAN}

\section{Pertumbuhan Padat Populasi L. sativae}

Pertumbuhan padat populasi $L$. sativae pada beberapa galur dan varietas tanaman tomat dapat diikuti dalam Gambar 1 dan 2 di bawah ini.

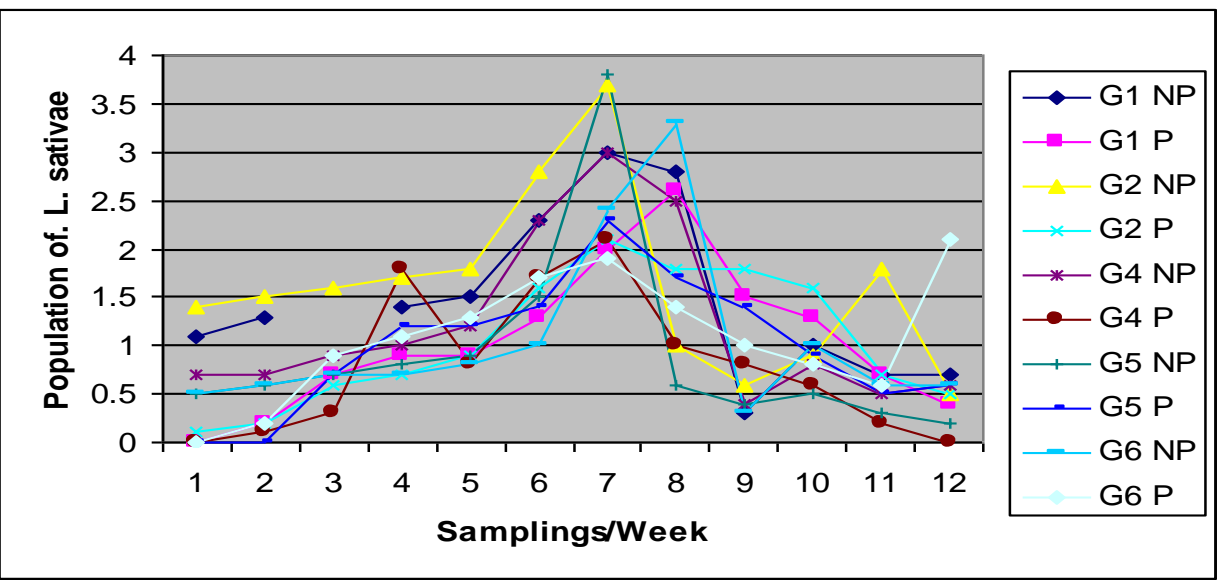

Gambar 1. Populasi L. sativae per Tanaman pada Galur G1 s/d G6 dengan Penyemprotan Pestisida (P) dan tanpa Penyemprotan Pestisida (NP)

(Figure 1. Population of $L$. sativae on strains 1 to $G 6$ with (P) and without (NP) pesticide spraying)

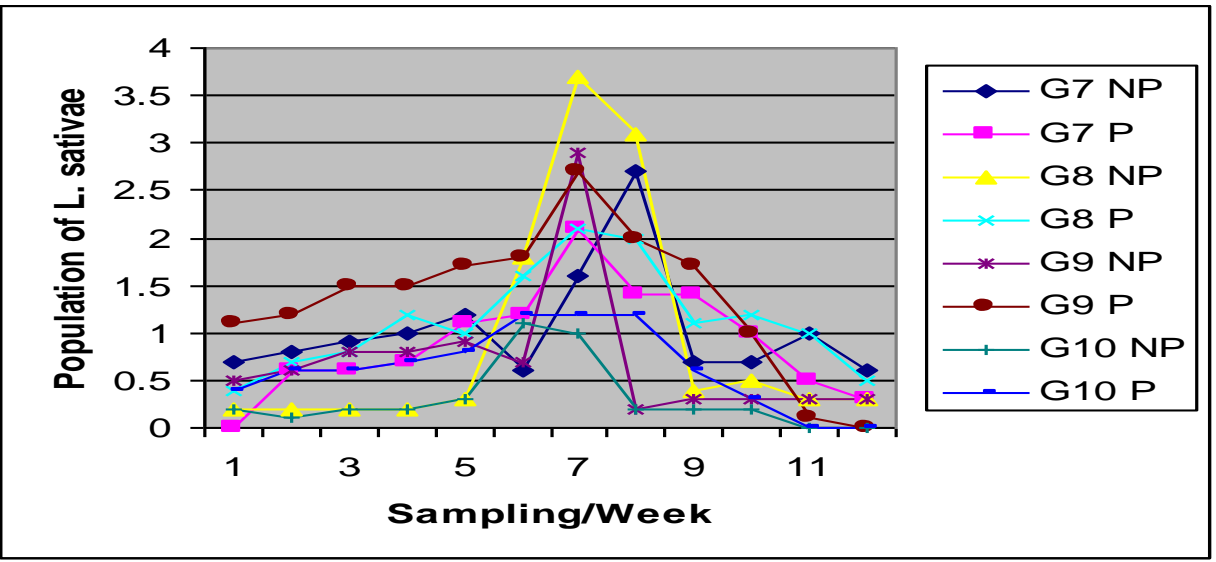

Gambar 2. Populasi L. sativae per tanaman pada galur G7 s/d G10 dengan Penyemprotan Pestisida (P) dan tanpa Penyemprotan Pestisida (NP)

(Figure 2. Population of L. sativae on Varieties G7 to G 10 with (P) and Without (NP) Pesticide Spraying) 
Gambar 1 dan 2 terlihat bahwa padat populasi penggorok daun, $L$. sativae berkembang mulai dari minggu ketiga (pengambilan sampel 1) sesudah tanaman dipindahkan dan meningkat dengan tajam pada pengambilan sampel ke 7 dan 8 kemudian turun secara drastis sampai pada pengambilan sampel ke 12. Populasi tertinggi untuk petak tanpa penyemprotan adalah pada galur G2 dan G5 sebesar 3.7 ekor per tanaman dan terendah pada varietas $\mathrm{G} 10$ (varietas Chung) yaitu berjumlah hanya 1.0 ekor per tanaman. Populasi tertinggi untuk petak dengan penyemprotan terdapat pada varietas G9 (Varietas Permata) yaitu sebesar 2.6 ekor per tanaman dan terendah pada varietas G10 (Chung) yaitu hanya sebesar 1.17 ekor per tanaman. Dari data-data ini terlihat bahwa varietas $\mathrm{G} 10$ adalah yang paling tahan terhadap serangan $L$. sativae.

Hasil analisis sidik ragam yang dilanjutkan dengan uji BNT 0.05 menunjukkan bahwa populasi lalat penggorok daun dengan penyemprotan pestisida varietas $\mathrm{G} 8, \mathrm{G} 9$ dan $\mathrm{G} 10$ serta galur $\mathrm{G} 5$ secara nyata lebih rendah dari galur G1, G2, G4 dan varietas $\mathrm{G}$. Pada petak tanpa penyemprotan varietas G10 memiliki populasi terendah dan berbeda nyata dengan galur dan varietas lainnya.

Populasi penggorok daun, L. sativae pada semua galur dan varietas pada petak penyemprotan dengan pestidsida pada jauh lebih tinggi dibandingan dengan petak yang diperlakukan dengan penyemprotan. Hasil ini berbeda dengan penemuan di Amerika Serikat dimana tanaman tomat yang tidak disemprot memiliki populasi $L$. sativae yang rendah karena penyemprotan membunuh musuh-musuh alami hama penggorok daun (Komunikasi probadi dengan Dr. M. Shepard dari Clemson University South Carolina dan Dr Muniappan dari Virginia Tech, Virginia, Amerika Serikat, Juli 2010).

Kandowangko dkk. (2003) melaporkan $L$. sativae diparasitasi oleh beberapa parasitoid dengan tingkat parasitasi oleh Hemiptarsenemus varicornis sebesar $20.3 \%$ pada pertanaman tomat yang biasa disemprot pestisida di Toure. Manoi (2010) melaporkan bahwa hama penggorok daun diparasitasi oleh parasitoid Hemiptarsenemus varicornis dengan tingkat parasitasi rata-rata $40.2 \%$ pada petak tanpa penyemprotan dan $38.14 \%$ pada petak dengan penyemprotan. Tingkat parasitasi ini jauh lebih tinggi dari yang dilaporkan oleh Sembel dkk. (2009) dengan tingkat parasitasi sebesar 18.0\%. Dari hasil pengamatan ini dan hasil-hasil penelitian sebelumnya ditemukan bahwa parasitoid $H$. varicornis dapat bertahan dengan baik pada petak-petak penyemprotan dan tanpa penyemprotan pestisida serta effektif untuk mengendalikan penggorok daun $L$. sativae. Arida et al., (2009) melaporkan bahwa insektisida klorpirifos ditambah dengan BPMC dapat menurunkan efektifitas musuh-musuh alami penggorok daun, Liriomyza trifolii (Burges) pada tanaman bawang (Allium cepa Linn.) di Filipina.

\section{Pertumbuhan Padat Populasi Nesidiocoris tenuis}

Pertumbuhan padat populasi kepik tomat dapat diikuti dalam Gambar 3 dan 4. Dari Gambar tersebut dapat dilihat bahwa populasi $N$. tenuis pada petak tanpa penyemprotan berkembang mulai dari pengambilan sampel pertama kemudian secara perlahan meningkat dan mencapai puncak pada pengambilan sampel ke enam untuk galur G2 dengan rataan populasi 9.27 ekor dan ke tujuh untuk galur G1, G4, G5, G6 dan G8 dengan rataan populasi masing-masing berturut-turut, $4.59,10.48$, 9.28, 9.03, dan 5.6 ekor per tanaman tomat. Populasi terendah pada pengambilan sampel terahkir yaitu ke 12 untuk semua galur dan varietas.

Pada petak dengan penyemprotan terdapat tendensi yang sama dengan pada petak tanpa penyemprotan dimana populasi $N$. tenuis berkembang mulai dari pengambilan sampel pertama dan mencapai puncak pada pengambilan sampel ke enam sampai ke delapan kecuali untuk varietas G10 dimana populasi $N$. tenuis tertinggi dicapai pada pengambilan sampel ke 3 yaitu sebesar 5.34 ekor per tanaman. Populasi galur G1 mewncapai puncak pada pengambilan sampel ke 5 yaitu sebesar 7.9 ekor per tanaman sedangkan G9 pada pengambilan sampel ke 6 deengan populasi sebesar 3.25 ekor per tanaman dan varietas G8 pada pengambilan sampel ke 7 dengan rataan populasi 3.72 ekor per tanaman. Galur G2, G4, G5 dan $\mathrm{G} 7$ populasi tertinggi terjadi pada pengambilan 
sampel ke 8 dengan masing-masing rataan populasi berturut-turut $3,65,4.36,4.66$, dan 3.86 ekor per tanaman Populasi terendah ditemukan pada pengambilan sampel terahkir yaitu ke 12 untuk semua galur dan varietas.

Hasil analisis ragam menunujukkan bahwa interaksi antar perlakuan dengan penyemprotan $(P)$ dan tanpa penyemprotan pestisida (NP) terhadap populasi serangga $\mathrm{N}$. tenuis tidak nyata tetapi antar galur dan varietas memberikan pengaruh yang nyata. Hasil analisis BNT 0.05 adalah 0.31 . Populasi $N$. tenuis dengan penyemprotan pada galur G10 adalah yang terendah yaitu 0.56 ekor/tanaman sedangkan pada petak dengan penyemprotan maka varietas $\mathrm{G} 7, \mathrm{G} 9$ dan $\mathrm{G} 10$ memiliki populasi terendah dibandingkan dengan galur-galur yang berasal dari AVRDC. Hasil ini menunjukkan bahwa varietas tomat yang sudah tersedia di pasaran Sulawesi Utara lebih tahan terhadap serangan $\mathrm{N}$. tenuis dibandingkan dengan galur-galur yang berasal dari AVRDC.

Hasil pengamatan di lapang dan laporan petani tomat di Toure menyatakan bahwa kehadiran $N$. tenuis paada tanaman tomat akhirakhir ini terutama sejak dua atau tiga tahun terahkir ini telah mengakibatkan kerusakan pada tanaman yaitu terjadinya keguguran bunga tomat sehingga tanpa penyemprotan dengan pestisida maka produksi buah tomat akan sangat berkurang (Komunikasi pribadi dengan petani di Toure, Mei 2010). Budiman dkk. (2010) menunjukkan bahwa kepik mirid ini dapat mengakibatkan kerusakan pada tangkai bunga dan batang atau cabang tomat dengan pembentukan cincin yang bewarna coklat yang pada akhirnya dapat mengakibatkan gugurnya daun atau patahnya tangkai tanaman. Arno et al. (2006) melaporkan bahwa tingkat serangan hama kepik ini terutama pembentukan cincin coklat pada tangkai tanaman akan tergantung pada populasi hama yang juga bertindak sebagai predator. Calvo et. al. (2008) dan Sanchez (2008) juga melaporkan bahwa tingkat serangan hama ini akan tergantung pada populasi dari serangga yang menjadi inang $N$. tenuis. Bila inang seperti kutu daun, dan serangga kecil lainnya tersedia sebagai makaman $N$. tenuis maka tingkat serangan hama ini akan berkurang.

Dari hasil penelitian Manoy (2009) ditemukan adanya perkembangan populasi kutu kebul, B. tabaci mulai dari pemindahan tanaman sampai panen. Hal ini memungkinkan terjadinya penghambatan terhadap pertumbuhan tanaman tomat karena adanya pengisapan cairan tanaman oleh hama ini tetapi juga memungkinkan terjadinya infeksi virus yang dapat ditularkan oleh $B$. tabaci.

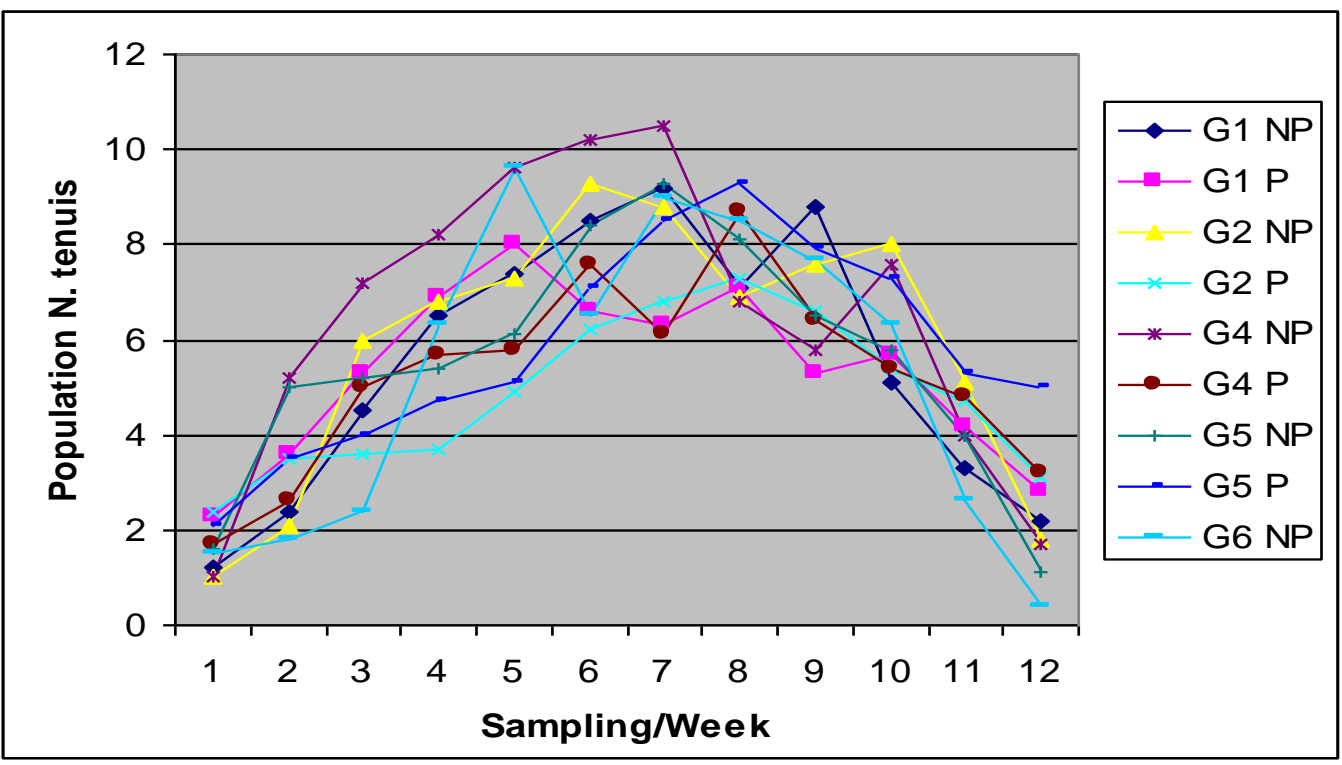

Gambar 3. Populasi N. tenuis per tanaman pada galur $\mathrm{G} 1 \mathrm{~s} / \mathrm{d} \mathrm{G} 6$ dengan penyemprotan pestisida ( $\mathrm{P})$ dan tanpa penyemprotan pestisida (NP)

Figure 3. (Population of N. tenuis on strains $G 1$ to $G 6$ with (P) and without (NP) pesticide spraying) 


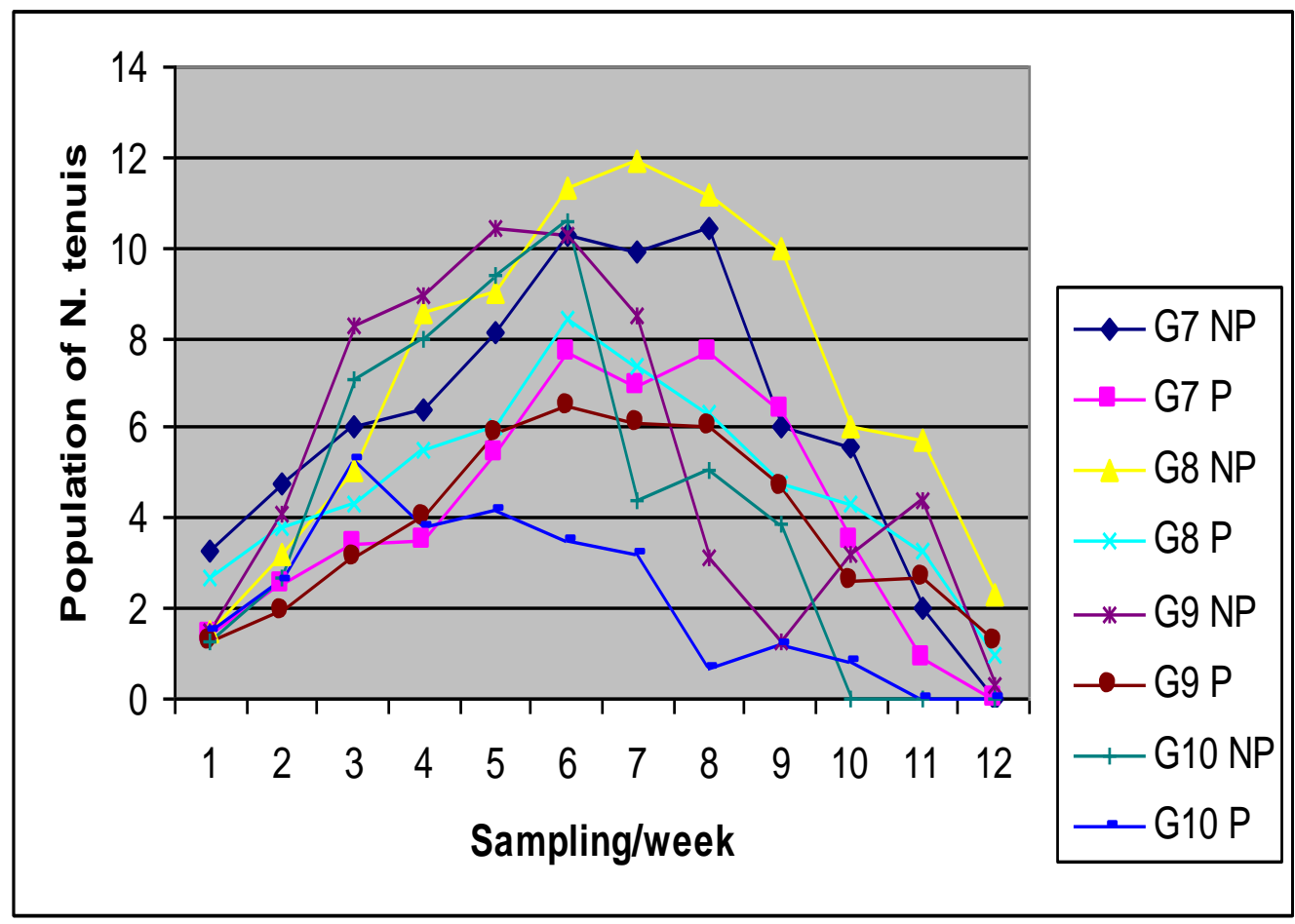

Gambar 4. Populasi N. tenuis per tanaman pada galur G7 s/d G10 dengan penyemprotan pestisida (P) dan tanpa penyemprotan pestisida (NP)

(Figure 4. Population of N. tenuis on varieties $G 7$ to $G 10$ with (P) and without (NP) pesticide spraying)

Dilaporkan juga bahwa apabila populasi $B$. tabaci tinggi maka $N$. tenuis akan lebih banyak memangsa kutu kebul ini daripada mengisap cairan tanaman tomat ( Capinera et al. 2007; Calvo et al., 2008 dan Sanchez et al. 2008). Tumilaar (2010) melaporkan bahwa semua galur (G1 sampai dengan G6) yang berasal dari AVRDC terinfeksi oleh virus dan varietas yang sudah tersedia di pasaran di Sulawesi Utara cenderung lebih tahan terhadap infeksi virus terutama G7, G8 dan G10. Varietas G9 yaitu tomat apel Permata yang paling banyak digunakan petani dilaporkan agak rentan terhadap infeksi virus (Tumilaar, 2010).

\section{KESIMPULAN}

Pertumbuhan populasi hama-hama Liriomyza sativae dan Nesidiocoris tenuis pada galur-galur yang berasal dari AVRDC cenderung lebih tinggi daripada varietas tanaman tomat yang sudah biasa digunakan oleh petani di Sulawesi
Utara baik pada petak tanaman tomat yang tidak disemprot maupun yang disemprot dengan pestisida. Tidak terdapat perbedaan yang nyata antara padat populasi hama-hama $L$. sativae dan $N$. tenuis pada petak-petak yang disemprot dengan pestisida dan tanpa penyemprotan dengan pestisida. Galur-galur yang berasal dari AVRDC tidak lebih tahan dari varietas-varietas yang sudah tersedia di pasaran di Sulawesi Utara. Varietas G10 (Chung) adalah varietas yang tingkat infestasi L. sativae, $N$. tenuis dan $B$. tabaci yang terendah.

\section{PENGHARGAAN}

Penelitian ini merupakan bagian dari tesis MSi Titov Manoi yang mendapat bantuan dana dari IPMCRSP/Virginia Tech USAID melalui kerjasama Clemson University South Carolina, USA dengan Universitas Sam Ratulangi Manado. 


\section{DAFTAR PUSTAKA}

Albajes, R. Castahe,C, Gabarra R., and Alomar. 2006. Risk of plant damage caused by natural enemies introduced for arthropod biological control, pp. 132-144.in Bigger, $F$, Bebendreler, D. and Kuhimann, U.(Editor). Environmental Impact of Invertabrates for Biological control of Arthropods: Methods and Risk assessment, Oxon, UK. CABI Pub.

Arida, G.S., B.S. Punzal, and E.G. Rajotte. 2009. Effect of xhlorpyrifos + BPMC insecticidespray on the population density, damage and natural enemies of leafminer (Liriomyza trifolii (Burgess) On onion , allium cepa Linn grown after rice (Oryza sativa Linn.) Phillipines. Entomologist : 23:56-66.

Arno, J., Castane,C, Riudavets,J., Roig,J. and Gabarra, R. 2006. Characterization of damage to tomato plants produced by the zoophytophagous predator Nesidiocoris tenuis IOBC/WPRS Bulletin 29(4), 249254. 2010.

Risk of damage to tomato crops by generalist zoophytophagous predator Nesidiocoris tenuis (Reuter) (Hemiptera:Miridae). Bulletin of Ento Res. 100: 105-115.

Budiman A.A. 2008. Biologi dan Ekologi Cyrtopeltis tenuis (Hemiptera: Miridae) pada Tanaman Tomat. Thesis Master. Program Pasca Sarjana Unsrat Manado.

Calvo, J., Bolckmans, K., Stansly, P.A. and Urbadeja, A. 2008. Predation of Nesidiocoris on Bemisia tabaci and injury to tomato. Biocontrol Document.

Carnero, A., Diaz,S., Amador,S., Hernandez, M and Hernandez, E. 2000. Impact of Nesidiocoris tenuis (Heteroptera:Miridae) on whitefly population in protected tomato crops. IOBC/WPRS Bulletin 23(1), 259.

Capinera, J.L. 2007. Vegetable Leafminer, Liriomyza sativae Blanchard (Insecta: Diptera: Agromyzidae). Department of
Entomology and Nematology, University of Florida. www.entnemdept.ufl.edu. Dinas Pertanian Tanaman Pangan dan Hortikultura. 2010. Laporan Tahunan.

El-Dessouki, S.A., El-Kifi,A.H., and Helal, H.A. (1976). Life cycle, host plant and symptoms of damage of the tomato bug, Nesidiocoris tenuis (Reuter) (Heteroptera: Miridae, in Egypt. Journal of Plant disease and Protection 83(4), 204-220.

Kalshoven, L.G.E. 1981. The Pests of Crops in Indonesia. Revised and translated by P.A. Van Der Laan. P.T. Ichtiar Baru Jakarta.

Kandowangko,D.S., J. Watung dan D.T. Sembel. 2003. Parasitoid Penggorok Daun, Liriomyza spp (Diptera: Agromyzidae) pada beberapa tanaman di Sulawesi Utara. Eugenia 9(4): 273-280).

Manoy, T. 2010. Jenis dan populasi serangga dengan dan tanpa penyemprotan pesticida pada beberapa galur dan varietas tomat. Tesis MSi. Program Pasca Sarjana Universitas Sam Ratulangi Manado.

Patel, N.G. (1980). The bionomics and control measures of tobacco bug, Nesidiocoris tenuis Reuter (Hemiptera: Miridae). Gujarat University Research Journal 5 , 60- 72

Sanchez, J.A. (2008). Factors influencing zoophytophagy in the plant bug, Nesidiocoris tenuis (Hemiptera: Miridae) on tomato yield. Agricultural and Forest Entomology 10(2), 75-80.

Sembel, D.T, D.S. Kandowangko dan J. Watung. 2003a. Survey on Liriomyza spp. In North Sulawesi. Disampaikan pada Simposium Entomologi.

Sembel, D.T, J. Watung dan D.S. Kandowangko. 2003b. Survey for Liriomyza spp(Diptera: Agromyzidae) on Vegetable Crops in North Sulawesi. Eugenia (9) 4: 195-202.

Shepard B.M, Samsudin and A.R. Braun (1998). Seasonal Incidence of Liriomyza huidobrensis (Diptera: Agromyzidae) and Its Parasitoids on Vegetables in Indonesia. 
International Jounal of Pest Management 44: $43-47$

Torreno, H.S. (1994). Predation behaviour and efficiency of the bug Cyrtopeltis tenuis against the cutworm, Spodoptera litura $(\mathrm{F})$. Phillippine Entomologist 9(4), 426-434.

Tugiyono, H. 2005. Bertanam Tomat. Penerbit PT. Penebar Swadaya, Anggota IKAPI. Jakarta.
Tumilaar, D. 2010. Ketahanan Beberapa Galur dan Varietas Tomat Terhadap Penyakit Virus dan Layu. Tesis MSi. Program Pasca Sarja Universitas Sam Ratuangi Manado.

Urbaneja, J. Y. A. dan Nannini. 2003. Listado Publicaciones: A. Urbaneja http:// www. Ivia.es/publicaciones \%20 Almeria. 2007. 